\title{
Macrothink
}

\section{Engineering Professors' Perspectives on Gender and Assessment of Teamwork}

\author{
Kacey Beddoes (corresponding author) \\ Department of Sociology \\ University of Massachusetts Lowell \\ 883 Broadway Street, Dugan 205 \\ Lowell, MA 01854 USA \\ Email: kacey_beddoes@uml.edu
}

Grace Panther

School of Chemical, Biological, and Environmental Engineering

Oregon State University

Corvallis, OR 97331 USA

Email: grace.panther@oregonstate.edu

Received: June 21, 2017 Accepted: July 5, 2017 Published: July 10, 2017

doi:10.5296/ijld.v7i3.11431ＵRL: https://doi.org/10.5296/ijld.v7i3.11431

\begin{abstract}
Teamwork is an important component of engineering education programs; however, when not facilitated well, it can be a site of gender biases. The aim of this article is to thematically explore what and how engineering professors think about gender in the assessment of teamwork. In 2014 and 2015, semi-structured interviews were conducted with 39 engineering professors in the United States. Interviews covered a wide range of topics, with one section of the interviews devoted to teamwork specifically. For this article, the parts of the interviews about assessment of teamwork are analyzed. It was found that most participants were unaware of the ways in which gender can influence assessment and did not attempt to mitigate biases in self-evaluation, peer-evaluation, or team presentations. Recommendations for best practice are offered.
\end{abstract}

Keywords: Teamwork, gender, engineering, assessment 


\section{Introduction}

Around the world, teamwork is an important component of engineering education programs (Beddoes, Jesiek, \& Borrego, 2010; Borrego, Karlin, McNair, \& Beddoes, 2013; Paretti, Cross, $\&$ Matusovich, 2014; Purzer, 2011). Employers and educators often promote teamwork as a means of developing important professional skills, and as a way of increasing diversity in engineering (Wolfe \& Powell, 2009; Purzer, 2011). However, "despite the clear emphasis on teamwork in engineering and the increasing use of student team projects, our understanding of how best to cultivate and assess these learning outcomes in engineering students is sorely underdeveloped (McGourty et al., 2002; Shuman, Besterfield-Sacre, \& McGourty, 2005)" (Borrego et al., 2013, p. 473). Furthermore, there is much evidence that minority students, including women, often have negative experiences on teams, and gender biases permeate all levels of teamwork (Chachra, 2012; Meiksins, Layne, Beddoes, Martini, McCusker, Rideau, \& Shah, 2016; Meadows, Sekaquaptewa, Paretti, Pawley, Jordan, Chachra, \& Minerick, 2015; Mills, Ayre, \& Gill, 2010; Tonso, 2007; Trytten, Pan, Foor, Shehab, \& Walden, 2015; Walden, Foor, Pan, Shehab, \& Trytten, 2015; Wolfers, 2016).

Those findings are troubling given the persistence of underrepresentation in engineering. Despite the decades of efforts to recruit and retain women and other minority engineering students, they remain significantly underrepresented in engineering (NSF, 2013). In fact, the percentages of women in engineering undergraduate programs have decreased in the early 2000s (Grose, 2006; NSF, 2013). In 1991, women earned 15.5\% of undergraduate degrees; in 2002 it was up to $20.9 \%$; but by 2010 it had fallen to $18.4 \%$ (NSF, 2013). Percentages of underrepresented minority women are even more troubling: they earn $3.9 \%$ of doctoral degrees, $7.9 \%$ of masters degrees, and $10.6 \%$ of bachelors degrees in engineering. Most gains made in enrollments of female engineering students have been at the graduate level, not the undergraduate level, and engineering is considered a "low participation field" compared to most other science fields (NSF, 2013).

The roles that teamwork may play in contributing to underrepresentation has been identified as an emergent research theme in need of further examination (Meiksins et al., 2016). In order to contribute to the current conversations on gender and teamwork in engineering education, and to better understand faculty members' pedagogical practices surrounding teamwork, the aim of this article is to thematically analyze what and how engineering professors think about gender in the assessment of teamwork.

The article begins with a brief literature review on team assessment in relation to gender. Next, the methodological grounding and the methods of the study are described. The findings are then presented and discussed. The article concludes by identifying recommendations for decreasing gender biases in evaluation of teamwork in engineering.

\section{Literature Review}

Evaluation, or assessment, in engineering courses is commonly seen as unbiased and gender-free. However, as summarized in Table 1, there are several ways in which gender and gendered communication differences can affect assessment of teamwork (Hartsock, 2005; 


\section{$\triangle$ Macrothink}

McIlwee \& Robinson, 1992; Mills et al., 2014). First, assessment of teamwork typically includes a final presentation. Gender factors into team presentations in several important ways. During team presentations in one study, men were rated as significantly more knowledgeable than women when they presented more of the technical slides (Meadows \& Sekaquaptewa, 2011). The same study also found that men answered more of the questions asked by the class, and that as the number of women on a team increased, the likelihood that men would answer the questions increased (Meadows \& Sekaquaptewa, 2011). Additionally, men more harshly judge "female typical speech" (e.g., self-effacing speech) which raises questions about gender in the assessment of presentations (Wolfe \& Powell, 2009).

Second, another component of assessing teamwork is peer evaluation. Here again, there is evidence of gender biases against women. It has been found in science and engineering that men rate team members based on gender and often rate men higher than women, despite women being equally, and often times more, qualified and/or educated (Joshi, 2014). Furthermore, when using a peer rating system that adjusts the final grade based upon fulfilling individual responsibilities, it was found that men gave themselves a slightly higher rating and received high ratings from their teammates than did women in an engineering course (Kaufman et al., 2000). To combat the effects of gender biases in assessment, females' contributions when working with men must be explicitly shown or documented so that females are not rated as being less competent or less influential during group work (Heilman \& Haynes, 2005).

Third, gender can factor into self-assessment when women self-assess, they are often harsher than men counterparts. Women were found to give themselves lower ratings and underestimate themselves (Kaufman et al., 2000; Pulman, 2010). Lower self-assessments by women can potentially be because they more frequently recall their mistakes in comparison to men (Richards \& Bilgin, 2012). However, it is promising to see that women have reported that their own performance increased as the number of women on the team increased (Meadows \& Sekaquaptewa, 2011).

Table 1. Summary of biases

\begin{tabular}{ll}
\hline Evaluation Component & Documented Bias \\
\hline Self evaluations & $\bullet \quad$ Women rate themselves lower than men rate themselves \\
Peer evaluations & - Men rate women lower than other men \\
Team presentations & $\bullet \quad$ Typically feminine speech acts judged negatively \\
\hline
\end{tabular}

On the other hand, not all studies have found gender biases in self and peer evaluations (Mishra, Ostrovska, \& Hacaloglu, 2015; Tucker, 2014). Recent research is beginning to provide insights 
into conflicting findings. Ostafichuk, Sibley, d'Entremont, and Shirzad (2015) found that sex (which they call "gender") alone did not account for evaluation biases, but when coupled with MBTI personality domains, statistically significant effects were found. For example, female-introversion was scored higher than male-introversion, and male-judging was scored higher than male-perceiving. Therefore, it may be that gender (meaning social schemas about men and women) is in fact coming into play in complex ways, even though the authors themselves do not discuss this nuance because they are equating gender to biological sex. This highlights the problem with conflating gender and sex, which has been discussed further elsewhere (Beddoes \& Borrego, 2011). Additionally, a systematic literature review is being conducted in order to better understand the features of the research landscape that can explain conflicting findings (Beddoes \& Panther, Under review).

We use the terms assessment and evaluation in their broadest sense, including both official and unofficial evaluations (judgments) made by professors and students. When considered only in terms of grades (marks), it may not be so apparent how assessment can be considered gendered, particularly when team members receive the same grade on a project. It is important to take a holistic view of how assessment during a team project may shape students' future experiences and outcomes in engineering education. For instance, a poor peer evaluation could be a factor in an already marginalized student's decision to leave her engineering program. Or, as another example, a professor may not be willing to write a strong recommendation letter for a student who did not present any technical parts of her team's project, assuming that she did not make a significant contribution. In other words, the official and unofficial judgments made about students' during teamwork can have consequences that go beyond grades.

\section{Methods}

The methodology behind this article is "studying up." Studying up means to study people in positions of higher social status or power, or institutions more generally (Nader 1974; Sprague, 2005). Studying up stands in contrast to "studying down," which is the trend in social science to study - and often locate problems within - groups and individuals in positions of lower social status and power (Nader 1974; Sprague, 2005). The tendency to problematize women students in engineering education research on gender has been critiqued (Beddoes, 2017; Mills et al., 2010; Pawley, 2013; Riley, 2008). As the dominant mode of inquiry, it has led to gaps in our understandings of what and how faculty members think about gender that are problematic for creating effective change mechanisms.

The participants for this study were 39 engineering professors (18 women, 21 men) at three public institutions in different parts of the United States. The institutions represented geographic and institutional-type diversity, including "R1" and undergraduate focused institutions. As summarized in Table 2, the interviewees represented a mix of Assistant, Associate, and Full professors and a mix of engineering disciplines. Several interviewees held administrative positions. On an open-ended, optional demographic form given at the end of the interview (which all participants chose to complete), seven identified as Asian or Asian/white, two identified as Black, two identified as Indian, and the remaining twenty-eight as White. Even though all participants worked in the United States, they were originally from ten 


\section{1) Macrothink}

different countries.

Table 2. Overview of Participants

\begin{tabular}{ll}
\hline Group & Number of participants \\
\hline Career Level & 15 \\
Full professor & 13 \\
Assistant professor & 11 \\
Associate professor & \\
\hline Gender & 21 \\
Men & 18 \\
Women
\end{tabular}

\section{Discipline}

Electrical/Compute

Civil/Environmental/Construction

Industrial/Operations/Manufacturing

Chemical/Biological

Mechanical

Aerospace

Nuclear

Materials

Biomedical

Other

Participants were recruited though maximum variation sampling and purposeful random sampling (Patton, 1990). Lists of potential interviewees were gathered from public university websites and then randomly generated lists of names determined who was contacted. 
Purposeful steps were also taken to recruit a full range of engineering disciplines, career levels, and an equal number of men and women. The goal was to recruit interviewees who were randomly selected in order to avoid a participant pool who all had involvement with "women in engineering" initiatives. However, the random sampling process did of enroll some participants with involvement with women in engineering initiatives and they were not excluded. Recruitment methods are described in greater detail elsewhere (Beddoes, 2015). The response rates at the three institutions were $28 \%, 40 \%$, and $17 \%$ respectively.

Semi-structured interviews (Singleton \& Straits, 2010) were conducted by the lead author in 2014-2015. The interviews averaged 60 minutes in length and were audio-recorded and then transcribed. The interview protocol was designed to cover a wide range of topics that have been identified in prior literature as contributing to the gendering of engineering and/or women's underrepresentation in engineering. The overarching aim of the interviews was to better understand what and how engineering faculty members think about gender in engineering, women's underrepresentation in engineering, and how they make decisions around gender in their classes. While many of the issues covered herein are relevant to other underrepresented groups, and sometime participants' responses were about other types of underrepresentation, the questions specifically asked about gender and women.

One section of the interviews was devoted to teamwork. Participants were asked about their practices, decision-making, and experiences vis-à-vis teaching teamwork. This section of the interview was developed from prior literature on gender and teamwork in engineering (Chachra, 2012; Mills, Ayre, \& Gill, 2010; Tonso, 2007). For this analysis, transcripts were coded in two stages. First, responses to the team-specific assessment questions were analyzed with an open coding approach (Corbin \& Strauss, 2014). Second, full transcripts were read for instances in which assessment of teamwork was discussed outside of the team-specific questions, and those responses were also analyzed with an open coding approach (Corbin \& Strauss, 2014). Responses from the first and second stage of analysis were then combined with axial coding with the intent of addressing the research questions and identify common categories of responses. Findings related to other aspects of teamwork, as well as other parts of the interviews, have been reported elsewhere (Panther \& Beddoes, 2015; Beddoes \& Panther, Revision under review; Beddoes, In press).

In recognition of the diversity of participants, we have chosen to identify them with numbers rather than pseudonyms in order to avoid any implication of cultural or national origins that pseudonyms can imply. Quotations were edited for readability by removing false starts and crutches of speech.

\section{Findings}

The primary findings related to assessment of teamwork were: 1) most participants were unaware of the ways in which gender biases can manifest in teamwork; 2) most participants do not take gender into consideration during assessment of teamwork; 3) existing assessment methods and instruments are not likely to capture problems experienced by women students; and 4) even when faculty members are actively trying to assess team processes and evaluate the inclusivity of teamwork, they encounter challenges. 
Very little thought was given to assessing or understanding how students actually experience teamwork at all, let alone as it is related to gender. Instead, the final product and/or presentation were typically the sole subject of assessment, and the dominant assumption was that when that is the case, there is no room for gender biases.

Approximately half of the participants used some kind of peer evaluations, and many of those who did, believed that they are not valuable in general and specifically not valuable for "seeing" gender biases. Most participants did not (consciously) think about gender when assessing teamwork and half do not assess participation in teamwork at all. Of those who use peer evaluations, none had ever noticed anything gendered; however, they also did not believe the peer evaluations would capture problems if they occurred. Peer evaluations were simply not seen as useful sources of information for anything in general, but some also recognized that women and other underrepresented students are not necessarily likely to report the problems they experiences - on peer evaluations or otherwise. The general lack of value of peer evaluations was conveyed by P9 who referred to them as just "noise":

I don't recall seeing any gender bias in that [peer evaluation], but frankly most of the results in the peer assessment are mostly noise. It's mostly everybody's pretty happy with most of the people on their team and nobody wants to make any strong statement and so they're all kind of giving them [ratings of] fours or fives [out of five]. [Male associate professor]

Building on that sentiment, P34 said that rather than reporting negative experiences, students from underrepresented groups are more likely to internalize them:

We do a CATME thing where they all evaluate each other. And so far there's not any feedback directly on gender in that saying person $\mathrm{X}$, person $\mathrm{Y}$ was crappy along [a] gender axis. But that would be the space where they would have the ability to say that. Again, I think report rates on that kind of thing would be really low, is my feeling. I think people just internalize that when it happens. They don't really report it. [Male assistant professor]

Echoing that, P37 (a female full professor) recounted a story about a woman student's edits to a team report being disregarded, saying "I've had students and I think they don't realize that they're being discriminated against in that way." As P12 put it: "Who's gonna complain? The privileged ones are the ones that are gonna complain...I don't know if they [students from underrepresented groups] would complain if they really had a problem."'[Female full professor]. It was also common to hear that women take a "back seat" during team presentations, but this was rarely seen as affecting assessment.

Two exceptions should be noted. One participant spoke in detail about how professors' biases could affect assessment of teamwork. P20 said "of course" gender affects assessment:

Because it's again this whole thing of structure determines behavior, even people's apparent attractiveness affects how people assess the work, and whether or not they're extraverted or introverted. There are all kinds of things people are unconscious of in their biases so of course I think that [gender affects assessment]. [Female full professor]

Likewise, P24 acknowledged: 
I'm going to fall into what's possibly a stereotype, and I actually know exceptions to this stereotype, but on average, men tend to be more assertive. And so when people are doing self-assessments, it would be quite easy to overly value the people that were more assertive. "Oh, this was my idea." [Male full professor]

Finally, it is worth sharing a story about what happened when P31 made an active effort to be more hands on in following and assessing what was actually happening in her teams. Students resisted the interference, and it turned out there was a serious problem in the team that she had not had any indication of even with the more hands-on approach:

I did have a case of this where I had an instrument I was using with the team. And I was using the instrument every two weeks. And so they were all upset with me because they had to fill out these surveys about what was going on in their team every two weeks. And I was meeting with each team. And they were working on the projects through the whole semester. And I had extra time. It was a small class. And so instead of lecturing, I'd be meeting with these teams. And I'd meet, like, every two weeks with the teams... Two weeks before finals the members of the team came to me and they fired the one African American student on the team. I mean, how can you do that? This is the first thing I've heard of a problem.... So it really is about training the faculty how to do this. [Female full professor]

Thus, even when instructors want to be more proactive about facilitating teamwork that is gender inclusive or inclusive of underrepresented groups more broadly, they are likely to encounter challenges and will need tools and resources to promote their success.

\section{Discussion and Conclusions}

Our findings reflect what one participant said during her interview: teamwork can support diversity in engineering, but only if we "teach faculty how to teach it." The findings share some similarities to those of Paretti, Cross, and Matusovich (2014) who found that the majority of engineering professors do not utilize recommended criteria for effective teamwork. Additionally, the findings align with prior research that found that engineering instructors spend most of their time planning for lectures, rather than other course components, such as teamwork (Peters, Beddoes, Brown, \& Chang, 2016). Based on these findings, we can conclude that engineering professors are not being taught how to mitigate gender biases in assessment. While this is perhaps not surprising, given that most professors are never taught anything about pedagogy, let alone gender and pedagogy, it does warrant attention if we wish to use teamwork in ways that promote inclusivity. Unless professors are taught how to proactively manage teamwork with the aim of inclusivity, teamwork will likely continue to promote the status quo.

It is clear from this study that faculty members need tools and resources in order to assess teamwork in ways that minimize the likelihood of gender biases. In conclusion, we offer several recommendations for strategies that instructors can use to minimize gender biases in assessment of teamwork. First, team roles should be assigned by the instructor and rotated so that all students gain experience in both technical and management roles. Then, during group presentations, each student should have an opportunity to present technical portions of the 
project. This will decrease the likelihood that men will be seen as more technically competent than women.

Second, pre-teamwork interventions should be used to teach students about common biases in self and peer evaluation. As discussed in the literature review, some of the problems that have been documented include negative judgments of typically feminine speech acts and a tendency for men to receive higher ratings on both self and peer evaluations.

Third, to increase the likelihood that women's contributions will be "seen" and valued, all students should list their individual contributions to the team project in order to receive full recognition for their work. This can be done on a self-evaluation form at the end of a class; but should also be done at least once mid way through the class in order to assess whether or not all students are contributing to the technical components of the project.

However, professors themselves also need further training to learn about gender biases before they can teach their students about them. With the aim of helping instructors facilitate more inclusive teamwork, including better assessment practices, we have created an online training tool that will be freely available online in late 2017 (Panther, Beddoes, Cutler, \& Kappers, 2017). When ready, the URL for the tool will be available here: $<$ http://www.sociologyofengineering.org $>$.

In addition to this online tool, we suggest that better peer evaluation tools are needed. As noted, participants widely stated that current forms and tools are not useful in general, and that they are particularly not useful for uncovering problems going on in teams. The development and testing of a peer evaluation tool designed to maximize the likelihood of detecting gender biases would be worthwhile.

It should be emphasized that this analysis is not intended as a critique of the individual professors who participated in this study. Rather, it is meant to provide new insights into professors' practices and decision-making around teamwork and highlight issues that need further attention from the engineering education community.

\section{Acknowledgements}

We thank those professors who shared their time and thoughts to make this work possible and those who helped arrange the interviews. This material is based upon work supported by the National Science Foundation under grant EEC \#1564571. Any opinions, findings, and conclusions or recommendations expressed in this material are those of the author and do not necessarily reflect the views of the National Science Foundation.

\section{References}

Beddoes, K. (In press). Selling Policy Short? Faculty Perspectives on the Role of Policy in Addressing Women's Underrepresentation in Engineering Education. Studies in Higher Education. https://doi.org/10.1080/03075079.2016.1266610

Beddoes, K. (2017). Institutional Influences that Promote Studying Down in Engineering Diversity Research. Frontiers: A Journal of Women Studies, 38(1), 88-99. 
https://doi.org/10.5250/fronjwomestud.38.1.0088

Beddoes, K. (2015). Detailing Recruitment Efforts to Interview Faculty about Gender in Engineering. Presented at the Research on Engineering Education Symposium, Dublin, Ireland.

Beddoes, K., \& Borrego, M. (2011). Feminist Theory in Three Engineering Education Journals: 1995-2008. Journal of Engineering Education, 100(2), 281-303. https://doi.org/10.1002/j.2168-9830.2011.tb00014.x

Beddoes, K., Jesiek, B. K., \& Borrego, M. (2010). Identifying opportunities for international engineering education research on problem- and project-based learning. Interdisciplinary Journal of Problem-Based Learning, 4(2), 7-34. https://doi.org/10.7771/1541-5015.1142

Borrego, M., Karlin, J., McNair, L. D., \& Beddoes, K. (2013). Team Effectiveness Theory from Industrial and Organizational Psychology Applied to Engineering Student Project Teams: A Research Review. Journal of Engineering Education, 102(4), 472-512. https://doi.org/10.1002/jee.20023

Beddoes, K., \& Panther, G. (Revision under review). Gender and Teamwork: An Analysis of Professors' Perspectives and Practices. European Journal of Engineering Education.

Beddoes, K. \& G. Panther. (Under review). Mapping the Integrated Research Landscape on Gender and Teamwork in Higher Education: 2000-2016. Presented at the Australasian Association for Engineering Education Annual Conference, Manly, Australia.

Chachra, D. (2012). The Perils of Teamwork. PRISM Magazine. Retrieved from http://www.prism-magazine.org/summer12/reinvention.cfm

Corbin, J., \& Strauss, A. (2014). The Basics of Qualitative Research: Techniques and Procedures for Developing Grounded Theory (4th ed.). Thousand Oaks, CA: SAGE.

Grose, T. K. (2006). Trouble on the Horizon. ASEE Prism, 16(October), 26-31.

Hartsock, N. (2004). The Feminist Standpoint. In S. Harding (Ed.), The Feminist Standpoint Theory Reader: Intellectual and Political Controversies (pp. 35-54). New York, NY: Routledge.

Heilman, M. E., \& Haynes, M. C. (2005). No credit where credit is due: Attributional rationalization of women's success in male-female teams. Journal of Applied Psychology, 90(5), 905. https://doi.org/10.1037/0021-9010.90.5.905

Joshi, A. (2014). By Whom and When Is Women's Expertise Recognized? The Interactive Effects of Gender and Education in Science and Engineering Teams. Administrative Science Quarterly, 59(2), 202-239. https://doi.org/10.1177/0001839214528331

Kaufman, D. B., Felder, R. M., \& Fuller, H. (2000). Accounting for Individual Effort in Cooperative Learning Teams. Journal of Engineering Education, 89(2), 133-140. https://doi.org/10.1002/j.2168-9830.2000.tb00507.x 
McGourty, J., Shuman, L., Besterfield-Sacre, M., Atman, C., Miller, R., Olds, B., ... Wolfe, H. (2002). Preparing for ABET EC 2000: Research-based assessment methods and processes. International Journal of Engineering Education, 18(2), 157-167.

McIlwee, J. S., \& Robinson, J. G. (1992). Women in Engineering: Gender, Power, and Workplace Culture. Albany, NY: State University of New York Press.

Meadows, L., \& Sekaquaptewa, D. (2011). The effect of skewed gender composition on student participation in undergraduate engineering project teams. Presented at the American Society for Engineering Education Annual Conference, Vancouver, BC, Canada.

Meadows, L. A., \& Sekaquaptewa, D. (2014). The Influence of Gender Stereotypes on Role Adoption in Student Teams. Presented at the American Society for Engineering Education Annual Conference, Atlanta, GA.

Meadows, L. A., Sekaquaptewa, D., Paretti, M. C., Pawley, A. L., Jordan, S. S., Chachra, D., \& Minerick, A. (2015). Interactive Panel: Improving the Experiences of Marginalized Students on Engineering Design Teams. Presented at the American Society for Engineering Education Annual Conference, Seattle, WA. https://doi.org/10.18260/p.24344

Meiksins, P. F., Layne, P., Beddoes, K., Martini, G., McCusker, M., Rideau, R., \& Shah, Y. (2016). Women in Engineering: A Review of the 2015 Literature. Society of Women Engineers (SWE) Magazine, 62(2), 44-65.

Mills, J. E., Ayre, M. E., \& Gill, J. (2010). Gender Inclusive Engineering Education. New York: Routledge.

Mills, J. E., Franzway, S., Gill, J., \& Sharp, R. (2014). Challenging Knowledge, Sex and Power: Gender, Work and Engineering. New York: Routledge.

Mishra, D., Ostrovska, S., \& Hacaloglu, T. (2015). Assessing Team Work in Engineering

Projects. International Journal of Engineering Education, 31(2), 627-634.

Nader, L. (1974). Up the Anthropologist: Perspectives Gained from Studying Up. In D. Hymes (Ed.), Reinventing Anthropology. New York, NY: Vintage Books.

National Science Foundation (NSF): National Center for Science and Engineering Statistics. (2013). Women, Minorities, and Persons with Disabilities in Science and Engineering: 2013. Special Report NSF 13-304. Arlington, VA: National Science Foundation.

Ostafichuk, P. M., Sibley, M. J., \& d'Entremont, A. G. (2015). Gender and Personality Type Influence in Peer Evaluation. Presented at the American Society for Engineering Education Annual Conference, Seattle, WA. https://doi.org/10.18260/p.24150

Panther, G., \& Beddoes, K. (2015). (How) Do Professors Think About Gender When Designing PBL Experiences? Presented at the Australasian Association for Engineering Education Annual Conference, Torquay, Australia.

Panther, G., Beddoes, K., Cutler, S., \& Kappers, W. (2017). Development of an Instructor 


\section{I Macrothink}

International Journal of Learning and Development

ISSN 2164-4063 2017, Vol. 7, No. 3

Training Tool for Inclusive Teamwork. Presented at the European Society for Engineering Education Annual Conference, Azores, Portugal.

Paretti, M. C., Cross, K. J., \& Matusovich, H. M. (2014). Match or Mismatch: Engineering Faculty Beliefs about Communication and Teamwork versus Published Criteria. Presented at the American Society for Engineering Education Annual Conference, Indianapolis, IN.

Patton, M. Q. (1990). Qualitative Evaluation and Research Methods (Second). Newbury Park, CA: Sage.

Pawley, A. L. (2013). "Learning from small numbers" of underrepresented students' stories: Discussing a method to learn about institutional structure through narrative. Presented at the American Society for Engineering Education Annual Conference, Atlanta, GA.

Peters, A., Beddoes, K., Brown, S., \& Chang, K. (2016). Transportation Engineering Instructors' Decision-Making Processes for Course Changes. ASCE Journal of Professional Issues in Engineering Education and Practice, 142(3), n.p. https://doi.org/10.18260/p.24150

Pulman, M. (2010). Assessing personal attributes in the group rehearsal. Music Education Research, 12(4), 395-414. https://doi.org/10.1080/14613808.2010.519383

Purzer, S. (2011). The Relationship Between Team Discourse, Self-Efficacy, and Individual Achievement: A Sequential Mixed-Methods Study. Journal of Engineering Education, 100(4), 655-679. https://doi.org/10.1002/j.2168-9830.2011.tb00031.x

Richards, D., \& Bilgin, A. (2012). Cross-Cultural Study into ICT Student Attitudes and Behaviours Concerning Teams and Project Work. Multicultural Education \& Technology Journal, 6(1), 18-35. https://doi.org/10.1108/17504971211216292

Riley, D. (2008). Engineering and Social Justice. San Rafael, CA: Morgan \& Claypool.

Shuman, L. J., Besterfield-Sacre, M., \& McGourty, J. (2005). The ABET "Professional Skills"- Can They Be Taught? Can They Be Assessed? Journal of Engineering Education, 94(1), 41-55. https://doi.org/10.1108/17504971211216292

Singleton, R. A., \& Straits, B. C. (2010). Approaches to Social Research. New York, NY: Oxford University Press.

Sprague, J. (2005). Feminist Methodologies for Critical Researchers. Walnut Creek, CA: AltaMira Press.

Tonso, K. L. (2007). On The Outskirts of Engineering: Learning Identity, Gender, and Power via Engineering Practice. Rotterdam: Sense Publishers.

Trytten, D. A., Pan, R., Foor, C. E., Shehab, R. L., \& Walden, S. E. (2015). Inclusion or Exclusion? The Impact of the Intersection of Team Culture and Student Identity and Pathway on Team Diversity. Presented at the American Society for Engineering Education Annual Conference, Seattle, WA. https://doi.org/10.18260/p.24273

Tucker, R. (2014). Sex does not matter: gender bias and gender differences in peer 


\section{Macrothink}

International Journal of Learning and Development

ISSN 2164-4063 2017, Vol. 7, No. 3

assessments of contributions to group work. Assessment \& Evaluation in Higher Education, 39(3), 293-309. https://doi.org/10.1080/02602938.2013.830282

Walden, S. E., Foor, C. E., Pan, R., Shehab, R. L., \& Trytten, D. A. (2015). Leadership, Management, and Diversity: Missed Opportunities within Student Design Competition Teams. Presented at the American Society for Engineering Education Annual Conference, Seattle, WA. https://doi.org/10.18260/p.24396

Wolfe, J., \& Powell, E. (2009). Biases in Interpersonal Communication: How Engineering Students Perceive Gender Typical Speech Acts in Teamwork. Journal of Engineering Education, 98(1), 5-16. https://doi.org/10.1002/j.2168-9830.2009.tb01001.x

Wolfers, J. (2016, January 8). When Teamwork Doesn't Work for Women. The New York Times. Retrieved from http://www.nytimes.com/2016/01/10/upshot/when-teamwork-doesntwork-for-women.html?_r=2

\section{Copyright Disclaimer}

Copyright for this article is retained by the author(s), with first publication rights granted to the journal.

This is an open-access article distributed under the terms and conditions of the Creative Commons Attribution license (http://creativecommons.org/licenses/by/4.0/). 